\title{
Principles for the study of the biography of Holy Prophet (peace be upon him) and orientalists approach
}

\author{
Dr. Farhat Aziz* \\ Dr. Samina Saadia ${ }^{* *}$
}

\begin{abstract}
:
Orientalists have discovered the original and ancient sources, tracked and collected manuscripts from around the world, edited them and published their translations in different languages. They have provided such a vast asset of knowledge on Islam that it is now inevitable for anyone who writes on Seerah and Islam. Their scholarly endeavors have generally been appreciated, but there has been a perception in Islamic circle that they did not use scientific honesty, impartiality and broad-mindedness in presenting Prophet's (peace be upon him) biography and Islam, but with misrepresentation and prejudice. They have deliberately distorted the events and made a concerted effort to distort the history of Islam. orientalists have written countless books on Islam not only in English but also in other languages, so all those who cannot directly benefit from the writings of Arabic or Muslims in general will read their books and understand the same in the world. What they want to tell and explain about Islam will not give them a true picture of Islam. Besides, future generation who see Islam through the eyes of these orientalists will also remain skeptical of Islam. In view of these circumstances, it is necessary to present a balanced and scholarly review of Hazrat Muhammad (peace be upon him) writings, openly acknowledging his (peace be upon him) strengths and exposing shortcomings. This is what the article under research tries to do.
\end{abstract}

Keywords: principles, study, biography, context, orientalists

\section{Literature Review:}

As far as the review of previous work on this topic is concerned, there are enough information about principles of Seerah (the biography of Holy

\footnotetext{
*Associate Professor, Lahore College for Women University, Lahore. farhatfcc27@gmail.com

**A Assistant Professor, Department of Islamic Studies, Sheikh Zayed Islamic Center, University of the Punjab, Lahore.dr.saminasaadia@gmail.com
} 
Prophet (peace be upon him)), but they are in an old style, not sufficient to refute the objections leveled by the orientalists, according to the modern research methodology.

Dr. Yasin Mazhar Siddiqui and Dr. Tufail Hashmi wrote articles on this topic, which is considered a very significant source in Urdu language research for this subject. Moreover, several other authors who minutely discussed the topic but their mention will uselessly prolong.

\section{Objectives of Research:}

In this research paper, the principles of the biography of the Seerah Prophet (peace be upon him) will be discussed. As orientalists want to rely on every tradition and secondary sources to describe their point of views about the biography of Holy Prophet (peace be upon him) but in this article some specific principles will be described to study the biography of Prophet (peace be upon him) and to evaluate the traditions on scholarly ways.

\section{Research Methodology:}

A well-known research methodology on a scholarly level based on content analysis is adopted in this article. Before critically examining the writings of orientalists, one must also look at the circumstances in which these books were written to identify the factors that have been at the heart of these scholarly endeavors. Here are some historical facts that will hopefully help us understand the nature of the case. Jews and Christians came into contact with Muslims at an early age. During the Meccan life period of the Prophet (peace be upon him), Jews and Christians had started objecting to the religion of Islam as well as they were opposed to the idols of the Quraish. This opposition intensified during the ten-year period of Medina. In particular, anti-Semitism and various forms of fiber medicine continued unabated. A lot of objections have been raised by them against the revelation of the Qur'an and the truthfulness of the Prophet (peace be upon him).

As Islam spread rapidly throughout the world and its popularity grew day by day, people began to take refuge in Islam in droves. The reality of Islam and its enlightening teachings began to captivate the hearts of the people and the whole world began to believe in the greatness of Islam. Its life-affirming message erased the appeal of other religions and the code of conduct of nations and their teachings. It was also a fact that except Islam, all the religious followers claims of that time were proving to be hollow and useless for human society. They did not have a satisfactory solution to 
the problems that arose in human life. On such an occasion, Islam played an important role as the Messiah of humanity and presented itself as the best code of human life. People responded to this invitation and fell in love with this religion. When will the enemies of Islam, especially the Jews and Christians, who are afraid of the growing progress of Islam, believe that Islam will prevail over us?

The birth of the Prophet (peace be upon him) in Bani Ismail instead of the Prophet of Israel increased the enmity of the Jews of Medina. This enmity increased the Harassment of the Holy Prophet (peace be upon him) due to conspiracies against him and anti-Islamic activities, first expulsion from Medina and then from Arabia, fall of the Roman Empire, occupation of Jerusalem by the increased ratio of Muslims was troubling the ruling class. With the rise of Islam and conquests, the ruling class of Christians lost political power, not only the interests of the religious class and the nobility and feudal lords were harmed but also the merchants were harmed and all together had failed. And they also feared that the rest of Europe would follow in the footsteps of Muslims. Therefore, all these sections made a concerted effort to take back their lost territories from the Muslims.

To achieve this goal, political forces, nobles, feudal lords, clergy and merchants all came together, and the support of the people was necessary to protect their interests and regain lost power. It was achieved by telling them that Islam is the greatest enemy of Christianity, that has destroyed the Christian world, that churches have been turned into mosques, and that Christians are being forcibly converted to Islam and that Christianity is in danger. " Arise and save their holy churches from this savage nation. The clergy, the orators, the writers and the poets have stirred up the Christian world against Islam. A flood of Christian armies came from Europe seeking to sweep the Islamic world. This is known as the military flood and the Crusades, which lasted for centuries. Leading scholar Ernest Barker ${ }^{1}$, referring to the early Crusades, stated that (Pope Urban II) preached the Crusades and called it a jihad against "infidels"2

From the House of Commons, the pope took command of the war against Islam. The religious leaders of the Christian world understood very well that we could compete with the Islamic world only by establishing a military system. Islam was declared the particular enemy of Christianity. The Christian governments of Europe united and fought for two hundred consecutive years in the Islamic Middle East at the behest of Pope Urban $\mathrm{II}^{3}$ with the apparent aim of snatching the holy places from Muslim control. Some orientalists ${ }^{4}$ have tried to give the term a broader meaning and called every confrontation with the Nation of Islam the Crusades ${ }^{5}$.

This is the time when not only the ignorant but also the severe and 
educated writers not only spread lies, rubbish and ridiculous things to provoke the people but also make very serious allegations against Islam. The failure of the Crusades, waged by religious leaders, further fueled Europe's hatred and bigotry. Then they attributed the most painful things to the Prophet to turn his defeat into victory. In this background and environment, it is not difficult to understand how much scientific honesty will be in what was written on Seerah and Islam.

In the atmosphere of hatred and enmity, while poisoning is going on everywhere and disgusting propaganda against Islam is going on, the educated class is also swept away. This flood could be stopped only by those who have the correct knowledge of Islam, who work with honesty and integrity and whose critical consciousness is awake and strong. But that was the only class that disappeared in Europe.

What were the sources of objections from medieval orientalists? Even the serious writers would freely copy the baseless and ridiculous things that the losers and the runaway soldiers had made famous in Europe, but where they felt the need, they would fabricate fictions. Defaming Islam, denigrating it as a false religion and doing evil to it was considered a service to Christianity, and misrepresentation was justified for it. For Example, "Few great men have been so maligned as Muhammad (peace be upon him). Christian scholars of medieval Europe painted him as an impostor, a lecher, and a man of blood. A corruption with his name, "Mahound" even came to signify the devil"6 It is also very difficult to copy the things that have been said in the glory of the Holy Prophet (peace be upon him). For example, in connection with the death of the Holy Prophet (peace be upon him), it was written: that he (peace be upon him) was eaten by dogs or by pigs... ${ }^{7}$ With time, as the age of wisdom in the West changed, they changed their strategy and started raising objections to the biography of the Prophet (peace be upon him) on scientific grounds (but) with very little emphasis and hypothetical arguments. They attributed every evil thing to the Prophet (peace be upon him). They fabricated the myth of the well, prepared stories of illness, expounded the conditions of revelation and made the spirit unconsciously delusional, imposed polygamy on narcissism, interpreted the hardships of the Prophet (peace be upon him) as luxury, and proved Islam to be a violent religion.

And the Prophet (peace be upon him), who was known as a patriot of Khurasan to prove his connection with the forefathers of Changez Khan, arranged a supposed trip to Spain, beat the drums of so-called education from monks, and narrated stories of training in the Christian army. False orders accused the blood of the thighs, slandered Christian office and divinity, then changed the course and forced even the demons of hell to 
seek refuge. Negative emotions always bleed for justice. The West knows the facts, but prejudice and enmity still cling to the $\operatorname{mind}^{8}$. Also, we can gauge how much nonsense has been said that the Norman Daniel had to start his book with the words: "The bearer of infidelity is not the infidel" orientalists usually write these words ${ }^{9}$.

It is not that authentic Islamic books were not in their knowledge or were out of reach. A significant number of orientalists have been so in modern times. Those, who have generously used their mental and intellectual abilities in the study of Islamic sciences and dedicated their lives. Islamic manuscripts that had been deprived of sunlight for centuries became acquainted with broadcasting and escaped the neglect and benevolence of ignorant and incompetent heirs. How many scholarly sources and important historical documents first came to light as a result of their efforts and scholarly interest and passion which enlightened the eyes of the scholars and researchers of the Eastern world and furthered their work of knowledge and research.

An Orientalist A.J. Wensinck ${ }^{10}$ has compiled a very detailed index for the derivation of hadiths from the books of hadiths and biography. In the same way, he has also supervised the compilation of Encyclopedia' of the words of the Hadiths. The Orientalist G. L. Strange ${ }^{11}$ and his book "Lands of the Eastern Caliphate" (Geography of the Eastern Caliphate) also fall under this category. All these writings and scholarly research efforts are proof that these writers and editors have not spared any effort / struggle and have given full proof of their sincere devotion to their subject in this long life of study and effort.

The famous German Orientalist, Carl Brockelmann ${ }^{12}$, is one of the greatest orientalists of our century. He was undoubtedly the scholar of Arabic literature. He has compiled such a comprehensive and informative list of Arabic books that no other book on the subject. Ibn al-Nadeem's "AlFihrist", Mustafa Tash Kubrazada's "Muftah al-Sa'dat", Haji Khalifa's "Kashf al-Zanoon", Ismail Pasha's "Idhah al-Maknoon" and "Hidayat alArifin" and even in the case of Yusuf al-Iyan Sircas's case, Allama Brookelman's history of Arabic literature is higher than that of any research in the "Research of the Press". Today, it is not possible to imagine a library of orientalists without this priceless book of Brockelmann. He was the same Brockelmann, when he becomes a staunch Christian and writes the history of the Muslim world with the feelings of preferential privileges of the European nations in his heart, continues to write such awkward things that many countries had to be banned his writings. Therefore, the entry of this book is closed in Pakistan as well. Dr. Abdul Quddus Hashmi writes: I read this book. I am amazed that this great 
scholar of Arabic books gives the name of books. It tells the name of the author and the year of his death. It also tells in which libraries and where the book is available. Why doesn't he ever open the books and read them? First of all, he read the books very little, those which he reads did not consider their traditions, then he created the causes and results in such a way that no one can think of such strange causes and results in the margins of a person. Why did this happen? The answer is nothing that while writing history, his mind, heart and mind were occupied by the ideas of the superiority of the European nations ${ }^{13}$. It is an undeniable fact that at least educated Europeans had the correct knowledge of Islam, but in their blind support of Christianity, they preferred myths and baseless rumors to facts. One of the reasons for this was that in his writings he addressed only Christians, and also wrote for them. And the Christian masses were undoubtedly pleased with statements that denounced Islam and mocked its principles. The writers had no idea what Muslims would say after reading these books. So he would write whatever he wanted without hesitation.

The first step in biography or research and writing is to identify, determine, search and edit the material. Ahl-e-Seerah generally derives only the narrations of Seerah from the books of Seerah. And the Ahl eHadith in the present era of claim have been using the books of Hadith only in basic sources and the comprehensive status of the researchers in ancient and modern times. Imam Bukhari, ${ }^{14}$ Muhammad bin Muslim bin Shahab $^{15}$, the narrations of Ibn Ishaq ${ }^{16}$ and Musa Ibn Aqaba ${ }^{17}$ are mentioned in the translations of the chapters. Compiled by Maulana Sayid Sulaiman Nadwi, ${ }^{18}$ Maulana Idrees Kandhalvi, Maulana Maududi ${ }^{19}$ and various biographers have both gained enlightenment from Ahadith, Seerah and from the divine source of the Holy Quran.

Ancient and modern biographers have established the principle of giving preference to the traditions of hadith over the traditions of biography in the event of a clash of traditions, which is generally considered to be golden, absolute, abrogated and unchangeable. The case of Maulana Shibli ${ }^{20}$ and Sulaiman Nadwi, Sirat- un-Nabi, have stated this principle as the only standard of truth. Whether it is Islam or the caste of the Prophet (peace be upon him) that is harmed by these Ahadith, and it hurts the established rules and principles. The memorizer of the hadith and the expert on the biography, succinctly formulated the principle of verification that the consensus of the pilgrims would be conclusive proof in the event of a clash or disagreement over the general and unique traditions of the hadith. Hafiz Ibn Hajar Usqalani ${ }^{21}$ and some other scholars have tacitly confirmed the principle of verification by confirming and prioritizing the traditions of Ahl-e-Seer or by criticizing and commenting on these hadiths endorsed. 
The requirements of tact, intellect, logic and philosophy, and sophisticated scientific and technical specialization also demand that the interpretation of an issue on which there is a general consensus of the experts or a general consensus of the majority should be given priority. The purpose of compiling biographies was not to provide details of biography of Holy Prophet (peace be upon him). Their aim was to derive an Islamic rule or jurisprudential issue from the original Ahadith of biography of Holy Prophet (peace be upon him) and the traditions and hadiths related to them. Retrieving or providing information on the biography of the Prophet (peace be upon him). has not been part of their great art. For this reason, their style of presentation is found separately in the form of Al-khabar alwahid, and unconnected traditions, and there is no coherent and consistent statement on any subject, be it their basic religious work, jurisprudential inference and research. More important and critical is the fact that they have the same hadiths, relics and traditions related to the Prophet's (peace be upon him). biography from which a religious issue, jurisprudential ruling, Islamic law, legislative point, legal matter and religious matter emerges. For this reason, they do not have the coverage of the entire biography of the Prophet (peace be upon him).

The aim of the Ahl-e-Seerah is to compile the information and materials about the caste and attributes of the Prophet (peace be upon him), the conditions and acquisitions of the covenant, the events and affairs of the age, and rules of the religion and all biographies and deeds. In the form of a statement, it is necessary to convey the path of love to all the devotees. That is why their method of editing and writing is different from that of the Muhadditheen. They compile the Akhbar $i$ Ahad and the traditions according to their thematic status, place and presents them in the biography according to the chronological order and time. In their case, the Asanad is so neglected that it hinders the continuity and communication of the Akhbar i Ahad. They also work in various narrations of Asnad in terms of topics and subjects. They divide the single narrative and the Khabar-alWahid into chronological ones, and then present the narrative of all the stages of life from the beginning to the end, as if it were a continuous, coherent and ongoing whole narrative becomes biography.

The biographer must collect as much information as possible from both the repositories, but also all make full use of the other sources of knowledge and gnosis. These include the verses of the Holy Qur'an, the commentary traditions of the great commentators, the technical and scientific research of the jurists, the valuable research and interpretations of the Imams of the dictionary and literature and many other Islamic sciences and arts. history, geography, psychology, etc. to includes valuable 
information from them. Unless the basic work of compiling and editing all available then biographical material is done, otherwise, there will be an information gap somewhere and biographical studies will be incomplete.

Obviously, in this diverse, colorful and fragrant pen of countless biographies and traditions, there will be an obstacle of conflict and animosity somewhere. The scholars of Islam and the scholars of sciences have formulated the principle of application and adaptation only to remove it. This will create harmony and love and balance and interaction in the seemingly opposite and contradictory traditions, because in general most of the conflicts are apparent and in fact the correct place, context and application of these different information. And due to lack of knowledge of adaptation, differences and conflicts are visible, and in fact they do not happen. If there is no evidence to resolve the conflict and the cause of the dispute, then the collective or majority decision of the biographers will be logical and decisive. It belongs to the scholars of knowledge, not to the Imams of the other world.

Ancient and modern biographers have given the books of the Prophet's biography in a triple form distribution views of the needs of different classes. Short biographies for general aptitude, lack of intelligence and knowledge for elementary students, medium biography books for average level readers and secondary students, and biographies of eminent scholars, researchers of arts, higher grades. Extensive compilations for scholars and intellectuals, etc., tried to meet the needs of the first and third of the three classes of the Islamic Ummah by writing long and short books on Seerah. In Urdu, Qazi Muhammad Sulaiman Mansoorpuri at least made a plan and explained the way to quench the thirst for knowledge of the three. It is a very natural and logical division and biographies should be prepared according to them.

Now comes the complex and difficult question of the method of writing and the style of writing, why and how to compile these biography books? Obviously, the style of writing of ordinary early biography books will be narrative. But don't rely on just one or two ancient books. It is important to use new information and materials from the books of ancient authors and medieval travelers. In Ibn Ishaq / Ibn Hisham, ${ }^{22}$ numerous ancient authors such as Hafiz Umayyad's Maghazi, Urwah ibn Zubair's Mughazi and other scholars' narrations are giving a place, which is a scholarly as well as a skill oriented responsibility. So far, they have been dismissed as merely new material, rarely reduced to inferior information. The information and narrations of Ibn Ishaq and Ibn Hisham or other well-known authors are definitive, nor is it comprehensive and prohibitive that the acceptance of other narrations and information will affect their infallibility and purity. 
Every one of them has the artistic right to receive and accept new and upto-date materials and traditions and customs which are vigilant in the Islamic realm of Seerah-e-Taiba. At most, it can be seen whether their traditional status and theological standards are in accordance with the popular and well-known tradition. It has often been observed that popular traditions do not stand out against the rare and new traditions based on both traditional standards. For example, the tradition of sponsorship of Abu Talib regarding the education and training and care of the young Prophet (peace be upon him) after the death of his grandfather Abdul Mutalib Hashmi is inferior to Zubair bin Abdul Muttalib Hashmi in both respects. Or the Umayyad Hashmi traditions of family unity in the Abd alManaf family are superior to the traditions that show animosity. In the adoption and acceptance of such new traditions and information, it is necessary to adopt the principle of application first, and in case of noncompliance, it is necessary to work with the principle of priority.

Seerah books, even if they were once for the sake of knowledge and wisdom, should now be more than mere accounts of events and merely superficial. Gone are the days of narrating events and biographies that could not give to the reader except mere repetition. Now is the time to go through the rigors of analysis and this is the requirement of art. Without it, new information cannot be stored in old repositories. Secondly, the knowledge of the reader and the student has become higher. They seek the rebuilding of the personality and the restoration of the covenant, and whether they like it or not, it is a technical requirement that presented in an analytical style, because in that case the essence of the Prophet (peace be upon him) and the perfections and achievements can be presented in their correct Islamic perspective, through which the scientific defense of the attributes of the Holy Prophet (peace be upon him) and the religious protection of Islam is also possible. Religious values and cultural issues can be confused with personal circumstances. Social, economic, political and all other human affairs can be harmonized. On the whole the spirit of the age, the soul of civilization and the genius of man can be fully recovered.

Only through analytical study and critical writing can the traditional position and status of the traditions of the Seerah narration be determined and the righteous be distinguished from the wrong. It has been the practice of art researchers among travelers to choose the right traditions and reject the wrong narration. For the achievement of this goal, they discuss the narration of the news and the narration (if there is a chain of narration) and find out its beauty and ugliness, and in the form of the correct narration accept it, and in the form of wrong tradition reject it. In the same way, they 
apply the principle of asma o rijal in the matter of news and traditions in any chain of transmission, just as they apply the principles to the standard of da'wah. In the topic on the biography of the Prophet (peace be upon him), the first and foremost principle should be whether it is worthy of the noble character, high personality and character of the Holy Prophet (peace be upon him). And secondly, does it conform to Islamic values, religious standards and religious spirit? Third, whether it is compatible with ordinary natural phenomena and logical biography, and most importantly, whether it adheres to other principles of art.

The traditional analysis of traditions and news in the Seerah of the Prophet (peace be upon him) should be done in the same way as it has been done in the events and circumstances during the time period of Prophet (peace be upon him). The events and news of the pre-Islamic period are generally unverified. Their traditional standard is more or less the same, that they are based on the Hifz news, ancient stories and events. Therefore, if a few such obscure traditions add to the popular traditions, then they should be included in the narrative biography without hesitation. For example, the greatest real uncle of the Holy Prophet (peace be upon him) was Zubair bin Abdul Muttalib Hashmi and he had a very important role in the life of the Prophet (peace be upon him) before his resurrection, but he is not mentioned with his other real uncle, Abu Talib bin Abdul Muttalib Hashmi. The persecution of the former and care of the Prophet (peace be upon him) is considered to be an act of deprivation in the training, disrespect and prejudice against the latter. However, it is prejudice and partiality that has usurped the right of the former.

According to Imam and philosopher of history Ibn Khaldun ${ }^{23}$, biased historiography is one of the seven crimes of writing and the sin of writing that distorts history. Undoubtedly, it is an intuitive and natural fact that every writer and every biographer is captivated by their own inclinations, tendencies, and prejudices, because no one is safe from the influence of natural demands and the workings of the psychic planets. it is to also be seen that they tend to hide, distort, misrepresent, half-truths, unjustifiably reject their inclinations and tendencies and prejudices. It cannot be said to be prejudiced, unbalanced or biased if he puts both or some aspects of tradition in the narrative. Ibn Ishaq / Ibn Hisham has committed partiality by concealing the real generality of Zubair bin Abdul Muttalib Hashmi's relationship with the Holy Prophet (peace be upon him) and giving the impression that Abu Talib is the "only real uncle". While Hafiz Umayyad and Imam Ibn Kathir and other scholars of art have openly expressed the two relationships and proved the truth, impartiality and objectivity.

The same founder of the philosophy of history, has presented a great 
theory of the external and internal aspects of history and has invented an infallible method of retrieving the reality which is purely Islamic in its structure and so-called. In their thinking, events, traditions, news are in fact external aspects of history which are not the real life and history of Seerah. The factors and elements that make up the appearance of these events, data and bring them to light are, in fact, internal or esoteric aspects of history, and the realization of reality can not be done without knowing and analyzing their actions, appearances. They are, in fact, the soul of history and the life of the Seerah, and the outward events, their objects, bodies and dimensions cannot be presented in words or phrases ${ }^{24}$.

The Prophet (peace be upon him) is a great personality of the world, far superior to other Prophets and founders of religions. Every aspect of His (peace be upon him) life is a beacon of light for mankind, which must be studied. In view of the completeness and comprehensiveness of His character (peace be upon him), the task of biography writing is not easy, but the experts, have considered a few principles necessary for biography writing of Prophet (peace be upon him) in modern times.

\section{Use of The Basic Sources of Seerah:}

It should base on the first and original sources of the biography of Seerah and it should not deviate from the Qur'an and Hadith, it should also not be written in the style of encyclopedia. In which all the information is filled without any discussion and it is considered necessary to present and have been accustomed all kinds of material. This style raises many unnecessary problems and questions that make the biography of the Prophet (peace be upon him) absolutely flawless and in which there is no need for Muslims to be obsessed and confused, because the pen of research has done its job (without accepting any effect of Orientalist skepticism) ${ }^{25}$.

\section{Good Expression, Order and Choice:}

The fact is that the Seerah, for its beauty, its suitability and elegance, and for its influence and charm, does not need the recommendation of a great man, the knowledge and wisdom of a sage, and the style of a writer or penman. What a writer needs at most is beautiful expressions, beautiful layouts and beautiful choices only ${ }^{26}$.

\section{Religious Beliefs and Facts:}

A biographer should be in tune with the religious beliefs and facts without whose light and guidance, it is difficult to properly understand the heavenly books, the biography, miracles of the prophets and the unseen events and facts. He should believe that this is the biography of a Prophet 
(peace be upon him) who was sent into the world by Allah and who had the help and support of Allah at all times, not the living conditions of any great national leader. He believes that this is a biography that can be presented to every fair-minded, educated person (whether Muslim or nonMuslim) without resorting to any reservations or interpretations ${ }^{27}$.

\section{Proficiency in Arabic:}

To write a biography, a biographer must be fluent in Arabic language and literature, have a taste for Arabic grammar, idioms and language and literature. According to Sayyid Sulaiman Nadwi: When some taste of Arabic language and literature arose, the researcher focused all his attention on the Arabic sources of Seerah. Among them were two books at the top of the list. One Ibn Hisham's book "Al-Seerat Nabawiyyah" ${ }^{28}$ and another Imam Ibn Al-Qayyim's ${ }^{29}$ book "Zad Al-Ma'ad" ${ }^{30}$. The author did not confine himself to reading books in a scientific or traditional way, but it would be correct to say that he spent his life in books. This was the time when the heart of author became acquainted with the sweetness of faith and belief, and his passion, and love found new nourishment and it was reirrigated because the "effective events of Seerah" were the most important of training and guidance. Which is a most effective source and life-giving for the human heart and mind (after the Qur'an) ${ }^{31}$. As the name suggests shows that these books were not written in Arabic but the authors were fluent in Arabic.

\section{Consultations of Ancient and Modern Biography Books:}

For a Seerah (biography), it is necessary to have a thorough knowledge of biography books written in Arabic, Persian, Pashto, Punjabi, English and other languages. According to Syed Sulaiman Nadwi: That is why Seerah has always been the greatest foundation of books and writings. His footsteps were full of style and color, and his footsteps refreshed its impressions of the pen. He used the strongest arguments and eloquence to explain its aims and demands. Examples were found in the beauty and perfection of Seerah itself created fluency and vibrancy in its nature and awakened dreamy abilities. There is no notable writing on which there is no mention of this beauty of Muhammad (peace be upon him). And there should be no reflection of deep study and contemplation of the Prophet's (peace be upon him) biography ${ }^{32}$.

The period in which these books came to light is considered to be the golden age of biography and the books of Ibn Ishaq, Urwah ibn Zubair, ${ }^{33}$ Ibn Sa'd ${ }^{34}$ and other biographers were used in that period. Therefore, Abdul Haq Mohaddess Dehlavi ${ }^{35}$ and Mulana Mubarakpuri quoted from 
these books and narrated the events of Seerah from their own and others narrations.

\section{Manifestation of Intellect and Emotions:}

It is reflected in many places in these books, then both the intellect and the emotions acted at the same time and side by side. And presented in a depressing manner, the beauty of the biography where there is an inevitable need to enjoy the views and enlighten one's mind and heart with it and its correct and perfect use and its problems, rules and events. It is a prerequisite to understand correctly and to reach the right conclusions. If a book of Seerah is devoid of this emotional and faith element, then it must be understood that it is an artificial structure of dry wood in which there is no heat and moisture of life. It is also important that this emotional and faith element does not override the requirements of common sense, the importance of which has been especially enhanced by modern times, nor does it contradict the correct, reasonable and comprehensible principles of logic, nor doctrine and imitation. There should be a tribute and a tribute that can only be accepted by the strong-willed Muslims and the righteous scholars whose have no connection with the outside world and modern culture.

\section{Love and Devotion:}

Wherever love of Prophet (peace be upon him) appears in these books, this devotion and love is undoubtedly a gift from Allah also enhanced but we must never forget that it is in any case the biography of the Prophet (peace be upon him) who has been sent as a mercy to all the peoples of the world and all classes of mankind, so it is forbidden or sealed for the people of this class It is not possible for those who have not been given the opportunity to develop in this Islamic, religious environment and the divine destiny has decided that they should be born in a non-Islamic environment, then they should develop there and then God's grace should help them and May a fragrant and life-giving breeze of the Seerah of Muhammad (peace be upon him) lift them up from this place through their heartfelt devotion and Christianity and bring them to the shadow of Islam, mercy and faith. The fact is that the right of these non-Muslims to Seerah is no less than that of the Muslims who are already in the shadow of Islam and faith, because a sick person needs more than medicine and treatment.

Environment of That Time and The Study of This Era:

For biography, the environment and the era of the time in which the sun of 
Prophethood of Muhammad (peace be upon him) rose for the first time cannot be ignored in any way, so it is necessary to take a complete picture of the universal ignorance of that era. In the sixth century, we have to look at the whole world. It also has to show the level of moral, social, economic and political condition of the people at that time. And what a case of tyrannical regimes, distorted religions, extremist and ideological philosophies, destructive movements and invitations doing their work, when the author of the book "Maza Khasara Al-Alam Bi Inhitat AlMuslimeen" as a prelude and precedent of the Age of Ignorance. When he tried to visualize the concept in detail, he encountered the difficulty that he still remembers. The history was narrated and collected these dispositions from all these huge books as if grains of sugar were collected from the mouths of ants ${ }^{36}$.

\section{Level of Intellect and Consciousness and Civilization:}

It is important to be aware of the level of intellect and civilization that existed at that time, as well as the collective and political and religious and religious conditions of this country, its economic and political structure and the nature of military and military power. He would also be aware of the true tendencies of the people of this country, their temperament, their minds and psychology, and would be able to fully comprehend the difficulties and obstacles that stand in the way of Islam's progress and advancement. The same can be said of Yathrib, where Islam migrated from Makkah, where the Prophet (peace be upon him) and his Companions migrated, and divine destiny made it the first center of Islam. The achievements of Islam cannot be estimated without understanding the scene.

What were the causes of corruption in the world at that time and what were the cases of oppressive governments, i.e. distorted religions, extremist and ideological philosophies, destructive movements and invitations, when the author of the book ' tried to conceive of the preIslamic era with a little detail as a prelude and precedent of "Maza Khasara Al-Alam Bi Inhitat Al-Muslimeen", he encountered such a difficulty that we may still remembers it? Without knowing these circumstances, we cannot understand how Islam trained and trained these people, how it revived them, how it solved various problems, how it thanked the warring factions. How did the Prophet Muhammad (peace be upon him) perform his duty of uniting broken hearts and reuniting the weeping human beings and their educational training and purification? This can only be understood when there should be a complete picture of the poor and complex environment that the Prophet (peace be upon him) and the 
Muslims had to face. Many events and decisions that pass through the eyes of man in the study of hadith and biography cannot be understood until Medina collective, economic and political status of the land, geography, surroundings, the individual and regional powers, their mutual relations, treaties and agreements and pre-migration affairs as well as national. The reader may not be aware of the country's customs and traditions. It would be like walking in a tunnel without knowing the beginning ${ }^{37}$.

Some modern biographers have also pointed out the importance of principles and traditions in biography of the Prophet Muhammad (peace be upon him). The narrators set certain conditions for examining the narration, in their view the narration will not be credible in the following cases and there is no need to investigate whether its narrators are reliable or not, but in some cases a few points.

Tradition which is against reason. Tradition which is against the principles of Islam. The Qur'an or the hadith should be continuous or against the definite consensus and there should be no room for refutation in it. The narrator who narrates from a person in such a way that no one else has done it and this narrator has not met that person. A narration that is such that all people need to be aware of it has not been narrated by anyone except one narrator. The narration in which such a remarkable event has been narrated that if it had happened, hundreds of people would have narrated it, despite the fact that only one narrator has narrated $\mathrm{it}^{38}$.

Maulana Shibli Nomani ${ }^{39}$ has presented the importance and high position of Islamic art tradition, intellect and wisdom in the light of the conduct of the Companions and the rules and principles of the critics of Hadith in the following points: First of all, one should look for the incident in the Holy Qur'an, then in the authentic hadiths, then in the general hadiths Seerah books need criticism and their traditions and credentials must be criticized. The narrations of Seerah are inferior to the narrations of authentic hadiths. Therefore, in case of disagreement, the traditions of the hadiths will always be given priority. Contrary to the traditions of the hadiths, the traditions of the masters of jurisprudence and consciousness will take precedence over others. It is very important to look for the cause and effect in the events of Seerah. The nature of the evidence should be based on the nature of the incident. What is the actual event in the tradition? And how much of the narrator's personal, opinion and understanding is included? What is the effect of external causes? Qur'an will not be valid. A tradition which is against common reason, common observation, general principle and the by applying and combining different traditions on an important subject, one should be convinced that there is no mistake in the meaning given to the narrator. Traditions of hadith should be accepted in terms of 
the importance of the subject and the relevance of the situation ${ }^{40}$.

All the narrators, whose efforts and endeavors have been of great benefit to the world, have also narrated in their books the hadiths which are related to the circumstances of his (peace be upon him) life, so these are the books of hadith from which the circumstances of his (peace be upon him) life can be found to be true and correct, and by arranging them in a reasonable way and distinguishing the correct from the wrong, a reliable account of his life can be gathered; as far as the hadiths from the circumstances of the Prophet (peace be upon him) are concerned. The books of the famous hadiths related to it are not worthy of being blindly accepted by us like the Book of Allah without consideration and without investigation, but it is obligatory upon us to accept all those Ahadiths whether they are from Bukhari, ${ }^{41}$ Muslim, ${ }^{42}$ Whether it is that of Jami 'AlTirmidhi, ${ }^{43}$ or that of Shumail al-Tirmidhi, Let us examine their truthfulness and correctness in accepting the truth with the principles and rules laid down for it. If we do not do so, we will fall into error because an unauthentic hadith has no place in the religion of Muslims ${ }^{44}$.

Muhammad Hussain Heckel claims that Western writers who attribute the political decline of Muslims to Islam, albeit to some extent, are disabled because the sources of Seerah (peace be upon him) writings are of two kinds: i.e. The writings of the friendly enemies of Islam \& the writings of ignorant Muslims of Islam.

The second type is to introduce into the religious things which God and His Messenger can never accept. The condition of the audacity of this sect is such that it issued a free ruling in favor of anyone who withheld their authority ${ }^{45}$.

Regardless, when we read books written by Muslims on the life of the Prophet, (peace be upon him) we are not surprised. There are many similar books in these journeys in which the footsteps of Hazrat Muhammad (peace be upon him) have been filled with something that makes the mind go crazy. On the one hand, these ignorant friends of Islam have considered these inventions and accusations as helpful in proving the Prophethood. However, they should deny prophecy. These inventions are the documents of those orientalists who consider it a duty of Orientalism to criticize Islam, the Holy Prophet (peace be upon him) and Muslims. We would not have cared so much about the nonsense that ignorant Muslim writers have blindly inserted into the books of Seerah, but Western writers have worked so eloquently to make the point of these contents. The original was deceived. They called this style of writing "Modern Research". They demanded that the discussion on which they wrote should be scrutinized with the same diligence as a fair investigation of an irrelevant subject 
matter. Sets aside and discusses the real issue. But in the writings of the orientalists, the controversy over Islam and the founder of Islam will be so clear. They presents this case in such a deceptive way that the followers may consider it to be the very truth; but the wealth of contentment and tranquility for the sake of God is bestowed on some of these free-thinking Christian writers whose Islam and its founder (peace be upon him) have not been far from justice ${ }^{46}$.

The general rationale for examining historical traditions is that each tradition can be accepted only after undergoing four tests. There is a rational possibility and a normal possibility for the event to be narrated. Although probability is not proof of fact, there must be both types of probability. The requirements of time and space should not be against the incident. This world is the world of causes, so any pre-existing event should be found necessary which could be the cause of this event. Each incident has its own effect, so it is important that the effects are created after the incident. And is a serious and reliable narrator or not and how did this narrator come to know about this incident? How much piety and honesty is found in the narrators themselves and their teachers? $?^{47}$

\section{Conclusion:}

This article presents an analysis of the principles of the biography of the Holy Prophet (peace be upon him) in Mecca and Medina, as civilian life based on historical evidence. A number of the events and commandments that go through the eyes of man by study of Hadith and Seerah books cannot be understood until the collective, economic and political condition of Mecca and Medina must be visualize. A biographer of that time must know the characteristics of the land, geography, surroundings, individual and regional powers, their interrelationships, treaties and covenants, matters before the migration, the national constitutions and customs etc. It will be important for the biographer to take full advantage of all this information in their work and take full advantage of the latest discussions and information that have come to light in the field of history, geography and comparative studies. Biography is a separate art which, is like the art of hadith, requires adherence to the principles of tradition and hadith. That is why the biographers who have written Seerah of the Holy Prophet (peace be upon him) in a research style have been complaining to the ancient biographers that they have not fully adhered to the principles of Da'wah with the tradition in Seerah of the Holy Prophet (peace be upon him). As a result of which suspicious and erroneous traditions have entered which have caused irreparable damage to the glorious edifice of Islam and Seerah of the Holy Prophet (peace be upon him) ${ }^{48}$. 


\section{Recommendations:}

In the end, it is appropriate to suggest to those orientalists who have been busy wholeheartedly in the completion of their mission by ignoring the Muhammad (peace be upon him) as last prophet of Allah, being nondeteriorate and not deny from his (peace be upon him) deputation in the chain of prophethood, that they must observe the authenticity of the seal of prophethood on Muhammad (peace be upon him) in the Holy Qur'an i.e.

Not is Muhammad (the) father (of) any one of your men but (he is the) Messenger (of) Allah and Seal (of) the Prophets. And Allah is of everything All-Knower ${ }^{49}$. and it is He who has sent among the unlettered a Messenger from themselves reciting to them His verses and purifying them and teaching them the Book and wisdom - although they were before in clear error ${ }^{50}$.

\section{References:}

${ }^{1}$ Sir Ernest Barker, (23 September 1874 - 17 February 1960) was an English political scientist

${ }^{2}$ Sir Thomas Arnold, Heritage of Islam, (Crusade: Ernest Barker) Urdu Translation by Abdul Majeed Salik, Lahore: Majlis Tarqi Adab, 1960, p.63

${ }^{3}$ (From about 1096 to 1296)

${ }_{5}^{4}$ (Such René Grousset 5 September 1885 - 12 September 1952)

${ }^{5}$ Zahoor Ahmed Azhar, Salibi Jangen, Lahore: Urdu Daira Marif-eIslamia, University of the Punjab, 1973

${ }^{6}$ Encyclopedia of Britannica, 1984, "Muhammad", V:12, p.609

${ }^{7}$ Bernard W. Lewis, Islam and the west, Oxford University Press, 1994, p. 40

Abdul Qadir Jilani, ISLAM, PAIGHAMBAR-E ISLAM, AUR MUSTASHRIQIN-E MAGHRIB KA ANDAZ-E FIKR, Lahore: Kitab Sarai,1431 AH / 2010 CE, p.62

${ }^{9}$ Bernard W. Lewis, Islam and the west, 3,5,6,40,68,79,92,97,101 Norman Daniel, Islam and the West: The Making of an Image (Paperback - April 1, 2009)

10 WENSINCK, A. J. (1882-1939), was a Dutch Semiticist, historian of Syriac mystical theology, and Islamicist

${ }^{11}$ G. L. Strange time period was $1854-1933$

${ }^{12}$ Carl Brockelmann (17 September 1868 - 6 May 1956) German Semiticist, was the foremost orientalist of his generation 13 “' Accessed December 29, 2020 
https://ilhaad.com/2016/03/mustashriqeen-aur-seerat/

${ }^{14}$ Abu Abdullah Muhammad ibn Isma'il Bukhari's time period was 81070 AD/194-256 AH

${ }^{15}$ Muhammad bin Muslim bin Shahab's time period was (47-742 / 51-124 $\mathrm{AH})$

${ }^{16}$ Muḥammad ibn Isḥāq ibn Yasār ibn Khiyār simply ibn Isḥaq, meaning "the son of Isaac" (died 767)

${ }^{17}$ Musa Ibn Aqaba's time period was 55-141 / 675-758

${ }^{18}$ Sayyid Sulaimān Nadwī; 22 November 1884 - 22 November 1953) was a Pakistani historian, writer and scholar of Islam. He co-authored Sirat-unNabi and wrote Khutbat-e-Madras

19 Maududi; 25 September 1903 - 22 September 1979) was a colonial Indian and Pakistani Islamist, Muslim philosopher, jurist, historian, journalist, activist and scholar

${ }^{20}$ Allama Shibli Nomani was born on 3rd June 1857 in Azamgarh Uttar Pradesh

${ }^{21}$ Ahmad Ibn e Hajar's time period was 773-852 / 1372-1449

${ }^{22}$ Abu Muhammad 'Abd al-Malik bin Hisham ibn Ayyub al-Himyari alMu'afiri al-Bașri or Ibn Hisham, edited the biography of Islamic prophet Muhammad written by Ibn Ishaq.

${ }^{23}$ Abdul Rahman bin Muhammad bin Muhammad Hazri Ibn-e-Khalddon's time period was 733-808 / 1332-1404

${ }^{24}$ Ibn e Khalddon, Muqadma (Cario: Musisa Al Ilmi Li Matbuat, ND) p.35-41

${ }^{25}$ Muhammad Tufail Hasmi, Naqoosh e Rasool Number, Idara Faroog-eAdab, Urdu, 1982

${ }^{26}$ Ibid.

${ }^{27}$ Ibid.

${ }^{28}$ Ibid.

${ }^{29}$ Shams al-Dīn Abū 'Abd Allāh Muhammad ibn Abī Bakr ibn Ayyūb alZur '⿳亠 1-Dimashqī 1-Hanbalī (29 January 1292-15 September 1350 CE/691 AH-751 AH), commonly known as Ibn Qayyim al-Jawziyya

${ }^{30}$ Muhammad Tufail Hasmi, Naqoosh e Rasool Number, Idara Faroog e Adab, Urdu, 1982

${ }^{31}$ Ibid.

${ }^{32}$ Ibid.

33 'Urwah ibn al-Zubayr ibn al-'Awwam al-Asadi (died 713) was among the seven fuqaha (jurists) who formulated the fiqh of Medina in the time of the Tabi'in and one of the Muslim historians

${ }^{34}$ Abū 'Abd Allāh Muhammad ibn Sa'd ibn Man̄̄' al-Bașrī al-Hāshimī or simply Ibn Sa'd and nicknamed "Scribe of Waqidi" (Katib al-Waqidi), 
was a scholar and Arabian biographer. Ibn Sa'd was born in 784 CE (168 $\mathrm{AH})$ and died on 16 February $845 \mathrm{CE}(230 \mathrm{AH})$

35 'Abd al-Haqq al-Dehlawi was an Islamic scholar. He was born in 1551 (958 AH) in Delhi, hence the suffix Dehlavi to his name. He became a writer in Arabic and Persian, who won favour from both Mughal Emperors, Jahangir (r.1605-28) and Shah Jahan (r.1628-58), and in time became a scholar of Islam

${ }^{36}$ Ibid.

${ }^{37}$ Ibid.

${ }^{38}$ Dana Puri, Kitab Mastab Asah ul Sair fi Huda Khair ul Bashar (peace be upon him), Karachi: Majlis-e-Nashriat, 1982, p.20

${ }^{39}$ Muslim leader. Influenced by[show] Influenced[show] Shibli Nomani 'Allāmah Šiblī No'mānī; 3 June 1857 - 18 November 1914, Azamgarh district) was an Islamic scholar from the Indian subcontinent during British Raj

${ }^{40}$ Maulana Shibli Nomani, Seerat-un-Nabi, Lahore: Maktaba Tameer-eInsaniyat, 1917, Vol:1, p.42-43

${ }^{41}$ Bukhārī (21 July 810 - 1 September 870 ), commonly referred to as Imam al-Bukhari or Imam Bukhari, was a Persian[3][4][5] Islamic scholar who was born in Bukhara (the capital of the Bukhara Region (viloyat) of what is now in Uzbekistan)

${ }^{42}$ Muslim ibn al-Hajjaj was born in the town of Nishapur in the Abbasid province of Khorasan, in present-day northeastern Iran. Historians differ as to his date of birth, though it is usually given as $202 \mathrm{AH}(817 / 818), 204$ AH (819/820), or 206 AH (821/822).

${ }^{43} \mathrm{He}$ wrote al-Jami as-Sahih (known as Jami at-Tirmidhi), one of the six canonical hadith compilations in Sunni Islam. He also wrote Shama'il Muhammadiyah (popularly known as Shama'il at-Tirmidhi), a compilation of hadiths concerning the person and character of the Islamic prophet, Muhammad

${ }^{44}$ Sir Syed Ahmed Khan, al-Khutbate al-Ahmdia, London, 1870, p.24

${ }^{45}$ Muhammad Hussain Heckel, Hiyat e Muhammad, Dehli: Taj Company, 1988 , p.20

${ }^{46}$ Ibid.

47 Ibn-e-Saad, Tabaqat, Translator: Allama Abdullah al Ammadi, Pakistan: Nafees Academy, Karachi, ND, Mulana Abdul Qaddus Hasmi, Preface, p. 9

${ }^{48}$ Syed Abul Hassan Nadvi, Nabi-e-Rahmat, Lakhnu: Nidwa tul Ullama, Majlis-e-Tahqiqat wa Nashriat e Islam, Edition 14th, 2013, Preface

${ }^{49}$ Al-Qura'an, Surah Al Ihzab Verse 40

${ }^{50}$ Al-Qura'an, Surah Al Jumu'ah Verse 02 